\title{
Tips For Maximizing The Value Of Your Retirement Investment Portfolio
}

Neal R. VanZante, (E-mail: n-vanzante@tamuk.edu), Texas A\&M University-Kingsville George R. Wagman, (kfgrw00@tamuk.edu), Texas A\&M University-Kingsville

Ralph B. Fritzsch, (E-mail: Ralph.frizsch@mwsu.edu) Midwestern State University

\begin{abstract}
Recent studies suggest that many retired and near-retirement age individuals do not understand basic investment strategy. One study concludes that "Boomers are in a state of financial paralysis" (Guardian Life, 2004). This article provides tips about which types of securities to include in various retirement accounts to maximize the value of the retirement portfolio. The article also considers social security and its possible effect on retirement investment strategy.
\end{abstract}

\section{INTRODUCTION}

A

recent survey released by Guardian Life Insurance Company of America provides evidence that many retired and near-retirement age individuals do not understand basic investment strategy. Baby Boomers don't know how much to save and they don't understand some basic financial principles such as compound interest and adequate returns, nor have they adopted any savings discipline. According to the Guardian Life findings, "Boomers are in a state of financial paralysis" (Guardian Life, 2004).

According to the $6^{\text {th }}$ annual Eaton Vance survey conducted in November, 2004, investors know little about tax-managed investing and are unable to identify the circumstances under which tax-managed investing is appropriate. Less than one-third of investors (31\%) are aware of investments specifically designed to maximize after-tax returns. Investors also demonstrate a lack of knowledge about what types of investments are best held inside of or outside of a qualified plan for tax purposes. For instance, more investors say they would be inclined to hold a tax-managed fund in a qualified retirement plan (43\%) rather than outside of a plan (42\%) and 16\% say they are unsure. Investors express concern about taxes and the tax implications of investing, but are confused by a subject that can, very quickly, become complicated," said Duncan Richardson, an Eaton Vance senior vice-president. "There is a great opportunity for financial advisers to help their clients" by discussing tax issues, he said (Cruz, 2005).

The purpose of this paper is to provide tips for maximizing the value of investments held in a retirement portfolio. First, the discussion focuses on investment securities (current income and growth). Next, discussion turns to types of accounts (taxable, tax-deferred, and tax-exempt). Then, advice about which securities are best suited to each type of account is offered in light of current federal tax laws. The paper concludes with consideration of social security and its possible effect on retirement investment strategy.

\section{INVESTMENT SECURITIES}

Investment securities generally designed to provide current income, growth, or a combination of the two. Current income securities include interest-bearing instruments such as savings accounts and bond investments, which can be tax-exempt (municipal bonds, for example) or taxable. Corporate cash dividends also provide current income. Corporations that reinvest earnings instead of paying cash provide growth instead of current income. Mutual funds that invest in both types of corporate stock provide a combination of current income and growth. 
Tax-exempt bonds usually offer a comparatively low interest rate, but the interest is not subject to federal income tax. As might be expected, these bonds are most advantageous to conservative, higher-income individuals. Taxable interest-bearing securities are, of course, subject to federal income tax.

Recent federal tax law changes provide for reduced tax rates (the same rate as for capital gains) for qualified corporate dividends. Thus, investment in stocks that pay cash dividends has recently become more popular (as compared to savings accounts and taxable bonds) and will probably remain popular as long as the favorable tax treatment lasts.

Growth stock provides several advantages. First, no federal income tax is due until the stock is sold. When the stock is sold, long-term gains receive favorable tax treatment due to the lower tax rates. Furthermore, if the stock is held at death, it passes on to heirs at its current market value and all appreciation escapes federal income taxation.

\section{TYPES OF ACCOUNTS}

Securities may be included within any of three account categories: taxable accounts (securities not held within one of the other two categories), tax-deferred accounts, and tax-exempt accounts. Tax-deferred accounts include 401(k) and similar employer sponsored defined contribution retirement plans as well as traditional IRAs. Taxexempt accounts include Roth IRAs. As the name implies, taxable accounts provide no tax advantage other than advantages identified with the specific security (tax-exempt bonds, for example). Because most readers are likely familiar with taxable accounts and employer sponsored defined contribution retirement plans, the focus of the remainder of this section is on IRA choices.

There are three types of IRAs. The choices are the Roth IRA, which offers tax-exempt earnings, the traditional deductible IRA that offers tax-deferment of deposits and earnings in the same manner as a 401(k), and the non-deductible IRA that offers tax deferment of earnings. Except for individuals who expect to be taxed at much lower rates in their retirement years and will require the IRA funds during retirement years, the Roth IRA is an obvious choice. For individuals who qualify for the Roth (income or age) but not for the traditional IRA, the Roth is a given. The non-deductible IRA is the last choice of the three and should only be considered by individuals who are not eligible for the other two. Other considerations associated with non-deductible IRAs are discussed later in this paper.

Traditional IRAs represent an especially popular and attractive investment alternative for purposes of retirement planning because individuals are allowed to deduct their contributions to IRAs in determining their taxable income. In addition, earnings on IRA funds are excluded from taxable income. Taxes are deferred until the funds are withdrawn, presumably after retirement when the individual may be in a lower tax bracket. Not only are taxes deferred for long periods, the retirement fund itself may increase substantially because larger contributions can be made.

For example, an individual in a $25 \%$ tax bracket who had $\$ 4,000$ of pre-tax earnings to invest in a retirement plan could invest the full $\$ 4,000$ in a traditional IRA. Only $\$ 3,000(\$ 4,000$ less tax of $\$ 1,000)$ would be available for investment in a taxable account. In ten years, assuming a $10 \%$ pre-tax rate of return, the $\$ 4,000$ invested in the traditional IRA would be $\$ 10,375$. If the amount is then withdrawn and the tax rate is still $25 \%$, net proceeds would amount to $\$ 7,781$. The invest of $\$ 3,000$ in the taxable account would provide only $\$ 6,183$. The traditional IRA option actually offers a bigger advantage than indicated because the individual could easily be in a lower tax bracket and because the fund balance will continue to provide continued greater earnings as it is withdrawn over a period of years.

Named after Senator William Roth of Delaware, the Roth IRA is a category of nondeductible IRA. Unlike other IRAs that offer tax-deferred earnings, the Roth IRA offers tax-exempt earnings. Qualified distributions from a Roth IRA are not included in income, and distributions are only required upon death. The Roth IRA offers several advantages over traditional IRAs. Individuals are allowed to contribute to Roth IRAs even after they turn age $701 / 2$, which is not allowed for traditional IRAs. Furthermore, individuals are not required to withdraw funds from their Roth IRA upon attaining age 
$701 / 2$ as they are required to do with traditional IRAs. Thus, investment in deductible IRAs require distributions to be made; investment in a Roth IRA does not. These required distributions result in taxable income and may place individuals in higher tax brackets, and individuals have less control over the timing of the distributions and the resulting taxes, including affecting the taxability of social security benefits for some individuals. Too, all withdrawals from a Roth IRA represent contributions first and then earnings. Therefore, no income tax or penalty is applied to premature distributions until all contributions have been withdrawn.

As mentioned above, Roth IRA distributions are not required until the taxpayer's death. However, wise estate planning may extend these tax-exempt earnings for many years, by passing along the IRA to a grandchild, for example. Another major advantage of the Roth IRA is the ability to effectively convert taxable investments to tax-free investments. Individuals may transfer existing IRAs to a Roth IRA penalty-free if their AGI is under $\$ 100,000$. However, the rollovers will be taxable in the year of transfer.

So, who should consider transferring existing IRAs to a Roth IRA? Similar to the decision about investing in a traditional IRA or a Roth IRA, the decision to transfer existing IRAs to a Roth IRA depends upon the assumed tax rates at time of withdrawals as compared to the date of transfer. If tax rates are predicted to be much lower and if the individual is close to retirement then the existing IRAs should probably be left alone. If tax rates are not predicted to be much lower or if the individual is far from retirement, converting existing IRAs to a Roth IRA is probably advisable assuming the individual has funds available to pay the taxes so they may avoid an early withdrawal penalty on the amount necessary to pay the taxes. To illustrate, assume an individual who is taxed at $25 \%$ has $\$ 10,000$ in an existing IRA. In ten years at a rate of $10 \%$, this IRA would grow to $\$ 25,937$. Assume the funds are then withdrawn and the tax rate is still $25 \%$, the aftertax available amount would be $\$ 19,453$. If the deductible IRA were converted, $\$ 2,500$ of tax would need to be paid. However, the full $\$ 25,937$ would be available ten years later. The difference of $\$ 6,484$ in ten years represents a tax-free investment of $\$ 2,500$ at the same $10 \%$ rate. In effect, then, the individual is allowed to make an additional $\$ 2,500$ tax-free investment.

Unless tax rates are expected to be lower at the time of withdrawals, conversion of existing IRAs to the extent allowed makes sense. But, even if a lower tax rate is anticipated, the issue of control and flexibility of retirement funds may be important enough to warrant conversion even if an individual is close to retirement.

\section{Which Securities Belong in Which Accounts}

As noted in the opening paragraphs, a large number of investors are confused about which securities belong in which accounts. One of the reasons for this confusion may be that any of the securities (nontaxable interestbearing, taxable interest-bearing, dividend paying, and growth stock) may be included in any of types of accounts (taxable, tax-deferred, and tax-exempt). Individuals have different preferences about the appropriate mix of securities to include in their retirement investment portfolio. The discussion here is limited to which securities provide the greater benefit in each type of account.

Nontaxable interest-bearing securities can be included in taxable accounts because there are no federal income taxes levied on the earnings. These securities could also be included in a Roth IRA, but there is no additional benefit of including them there. These securities definitely do not belong in any tax-deferred accounts because taxexempt income eventually becomes taxable. Thus, the only real place to include nontaxable interest-bearing securities is in a taxable account.

Taxable interest-bearing securities are best included in a Roth IRA because all earnings are tax-exempt. They also provide benefit when held in tax-deferred accounts, and they provide the least benefit when held in taxable accounts. This does not mean that investors receive the greatest benefit by including taxable interest-bearing securities in a Roth IRA. What is meant here is that, for the investor who wishes to include interest-bearing securities in their retirement investment portfolio, the Roth IRA provides the most favorable treatment.

Because current tax laws provide preferential treatment for long-term capital gains and because these capital gains are not taxed until they are realized, inclusion of growth-oriented securities in a tax-deferred account does not 
provide as much advantage as does the inclusion of taxable interest-bearing securities. In fact, inclusion of growthoriented securities in tax-deferred accounts may "back fire" to some extent because withdrawals (which include longterm gains) are taxed as ordinary income. As noted earlier, gains on growth stock held in a taxable account are not taxed until the stock is sold. Furthermore, recall that capital gains on growth stock held at the time of death escapes federal income taxes. The same gains accumulated in a tax-deferred account are subject to tax as ordinary income. Including growth stocks in a Roth IRA (tax-exempt account) provides the benefit of no federal income taxes as compared to lower income taxes for those who will be withdrawing funds during their life times. For those who plan to leave their Roth funds untouched during their life times, there is no additional benefit offered by placing the growth stock in a Roth IRA as compared to a taxable account.

Prior to recent changes in federal income tax laws, dividend-paying corporate stock was treated essentially the same as taxable interest-bearing securities. However, because qualified corporate dividends are now taxed at lower rates than ordinary income, they offer much the same advantage as growth stocks. However, because the dividend payments create current income, taxes are levied each year. Thus, holding these securities in a Roth IRA provides some benefit, and holding these securities in a tax-deferred account may provide some benefit if the individual's tax rates are lower when the funds are withdrawn.

Earlier, the non-deductible IRA was identified as the IRA that should only be considered by individuals who are not eligible for the other two kinds of IRAs. In fact, there are better choices than the non-deductible IRA, such as investment in growth stocks for the reasons discussed above. However, taxpayers may still benefit from contributions to non-deductible IRAs (as compared to no contribution) by including non-growth securities. Too, converting the non-deductible IRA to a Roth IRA in a later tax year when their income allows could provide the same advantages discussed earlier for converting a traditional IRA to a Roth IRA.

\section{Social Security Considerations}

In a recent article, VanZante and Fritzsch (2003) provided examples of how Social Security recipients may be subject to extremely high marginal income tax rates because they must add 50\% (or $85 \%$ ) of their Social Security benefits to their adjusted gross income. In that article, the authors provided several suggestions about how to reduce or avoid the tax on social security benefits. Suggestions included realigning investments from taxable securities to growth stocks and Series EE bonds (that pay interest only when they mature), taking advantage of lower required distributions on traditional IRAs and other retirement plans, using Roth funds and other non-taxable sources of funds, and converting traditional IRAs to a Roth IRA. As discussed in that article, although individuals are taxed currently on the amount of funds converted, earnings and distributions from the Roth IRA are tax-exempt. This strategy could be especially beneficial if the conversion occurs before Social Security benefits begin. The authors further suggested that individuals might consider rolling over $401(\mathrm{k})$ and other similar retirement funds over to a traditional IRA, then converting the resulting traditional IRA to a Roth IRA. The authors further noted that individuals may find these rollovers and conversions highly favorable even without the added benefit of reducing the tax on future social security benefits.

Withdrawals from the Roth IRA are not included in Adjusted Gross Income, so they do not cause social security benefits to be added as would be the case if withdrawals were made from traditional IRA and other tax deferred retirement funds. Of course, principal withdrawals from taxable accounts could also be made without causing additional amounts of social security benefits to be added. In other words, individuals can benefit by reducing the amounts of required distributions from tax deferred retirement plans and making up the deficiency in needed funds by drawing on tax-exempt and/or taxable investments.

\section{SUMMARY AND CONCLUSIONS}

This paper provides tips about which types of securities to include in various retirement accounts to maximize the value of the retirement portfolio. The advice offered is in the context of current federal tax laws. Tax laws are subject to constant change, and individuals need to keep abreast of these changes and be prepared to adjust their retirement portfolio holdings accordingly. 


\section{REFERENCES}

1. Cruz, Humberto, Penny-wise, tax foolish costs investor. Corpus Christi Caller Times (January 23, 2005).

2. Eaton Vance Corporation. Inside the Mind of the $21^{\text {st }}$ Century Investor.

3. http://biz.yahoo.com/bw/041207/75501_1.html (2005).

4. Guardian Life Insurance Company Press. Baby Boomers are in a State of Paralysis about saving for Retirement. www.guardianlife.com/company_info/press_releases/october_21_2004.html (2004)

5. VanZante, Neal R. and Fritzsch, Ralph B. Dodging the Bullet. Today's CPA (July/August, 2003

\section{NOTES}


NOTES 